\title{
Kirjoja
}

Jarmo Kortelainen ${ }^{a}$

\section{Tietotalouden geopolitiikkaa ja tilatulkintoja}

Moisio, Sami

Geopolitics of the Knowledge-Based Economy. Routledge, London and New York, 20 I8. (I 82 s.)

Sami Moision vuonna 2018 julkaistu kirja on saanut hyvän kansainvälisen vastaanoton. Se sai merkittävän RSA Routledge palkinnon vuoden 2019 parhaasta kirjasta, ja samana vuonna kirjan ympärille järjestettiin arvostettu Author meets critics -sessio maantieteen tärkeimmässä kansainvälisessä konferenssissa (Annual meeting of the American Association of Geographers) (Sellar ym. 2020). Kotimaassa teos on jäänyt vähemmälle huomiolle, eikä siitä ole tiettävästi kirjoitettu myöskään suomen kielistä arviota tätä ennen (vrt. Ritvala \& Piekkari 2021).

Moision kirja edustaa eräänlaista (geo)poliittista talousmaantiedettä, jossa tietotalouden ja politiikan suhdetta tarkastellaan vastavuoroisena, toinen toistaan muokkaavana prosessina. Geopolitiikan tutkimusta lähinnä vain toisella silmällä seuranneelle lukijalle kirjan teema on pääotsikosta lähtien virkistävä ja ajatuksia herättävä. Perinteisesti geopolitiikkaan on liittynyt varsin tunkkaisia mielikuvia valtioiden välisestä ja usein sotilaallisesta kamppailusta territoriaalisista resursseista ja valta-asetelmista. Sittemmin kulttuurisen käänteen myötä kriittisen geopolitiikan tulkinnat ovat siirtyneet tarkastelemaan maantieteellistä tietoa ja geopoliittista puhuntaa jälkiteollisessa tilanteessa. Moision kirja jatkaa metodologiselta otteeltaan kriittisen geopolitiikan linjoilla. Ilmiön materiaalisuus ja siihen liittyvät käytännöt saavat toki oman sijansa, mutta tarkastelu kulkee paljolti diskurssit ja mielikuvatulkinnat edellä.

Käytän työn avainkäsitteestä knowledge-based economization suomennosta tietoperustainen taloudellistuminen silläkin uhalla, että termille saattaa löytyä jo parempikin käännös. Teoksen keskeinen tavoite on kehittää tätä käsitettä ja samalla nähdä se geopoliittisena ilmiönä. Globaali tietoperustainen talous näyttäytyy verkostomaisena kokonaisuutena, joka rakentuu performatiivisina, itse itseään toteuttavina diskursseina, materiaalisina käytäntöinä sekä geopoliittisen toiminnan ja puhunnan subjekteina. Geopoliittisen tästä talouden muodosta tekee se, että valtiot, alueet ja kaupungit käyvät kamppailua asemistaan globaaleiksi muodostuneilla tietotalouden "taistelukentillä". Vallitsevan tietotaloudellisen ajattelun mukaan globaalissa kilvoittelussa menestyvät ainoastaan ne paikat ja alueet, joilla on kyky ja valmiudet luoda ja oppia uutta, tuottaa tietoa ja vetää puoleensa tietotalouden toimijoita.

Tietoon perustuvasta kilpailukykydiskurssista ja -mielikuvasta on siis tullut itsestään selvyys ja ainoa mahdollisuus, jolla valtioiden, alueiden ja kaupunkien kehitystä ja kilpailukykyä on voitu rakentaa, arvioida ja mitata. Tällaista mielikuvastoa ovat tuottaneet kansainväliset organisaatiot, ajatushautomot, akateemiset tutkija, konsultit ja

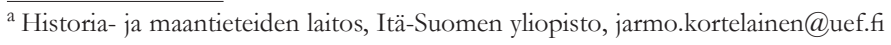


lukuisat muut tiedon tuottajat. Ajatusmalli on kulkeutunut tehokkaasti läpi poliittisten järjestelmien ja toimijoiden aina EU:n ylivaltiolliselta tasolta kansallisiin politiikkoihin sekä paikallisiin käytäntöihin. Tämä näkyy erityisen selvästi viime vuosikymmenten aluepolitiikassa, joka on painottanut kilpailukykyä, innovaatioita, inhimillistä pääomaa, luovuutta ja verkostoitumista aluekehittämisen perustoina EU:n tasolta aina paikallisiin kehittämistoimiin saakka. Tällainen ajattelu on muodostunut ainoaksi totuudeksi ja tavaksi kehystää tilanmuodostukseen liittyvää poliittista toimintaa.

Moision toinen keskeinen lähtökohta ja kantava ajatus liittyy geopoliittisiin tilatulkintoihin. Vaikka tietoperustaista taloudellistumista tukevat ja rakentavat verkostomielikuvat ovat tulleet merkittäviksi geopolitiikan ymmärtämisen määrittäjiksi, ne eivät ole syrjäyttäneet perinteisempiä territoriaalisuuteen perustuvia järjestelmiä, prosesseja, diskursseja ja käytäntöjä geopolitiikkaa jäsentävinä ja toteuttavina voimina. Viime vuosikymmeninähän on ilmestynyt runsaasti kirjallisuutta siitä, kuinka olemme tulleet uuteen vaiheeseen, jossa globaali tila ei jäsenny enää valtioiden tai muiden territoriaalisten yksiköiden mukaan. On väitetty, että tavallisesti uusliberalismiin liitetyt virtojen tilat ja solmut globaalisti levittäytyvissä verkostoissa ovat syrjäyttämässä territoriaalisuuden rajoineen ja alueellisine resursseineen. Moisio kieltää tällaisen lineaarisen transition ja korostaa kahden tilallisuuden samanaikaisuutta ja sekoittumista. Valtiot ja muut alueelliset toimijat toimivat samanaikaisesti sekä territoriaalisessa että relationaalisessa tilassa pyrkiessään hyödyntämään ja kasvattamaan tietopohjaisia resurssejaan, jotta menestyisivät globaaleissa tietointensiivisen kapitalismin kamppailuissa.

Kirjan kolmas kantava maantieteellinen teema liittyy kaupunkien ja metropolisaation keskeiseen rooliin tietoperustaisen geopolitiikan muotoutumisessa. Suurten kaupunkien rooli globaaleina toimijoina ja kansakuntien kilpailukyvyn moottoreina on korostunut niin diskurssien ja aineellisten prosessien kuin politiikkakäytäntöjenkin tasolla. Vallitsevan ajattelutavan mukaan ainoastaan riittävän kokoiset kaupungit voivat synnyttää ympäristöjä, joihin kansakunnan kilpailukyvyn kannalta elintärkeät tietotalouden pääomat kasautuvat ja taloutta pyörittävät luovat luokat kerääntyvät. Valtioiden menestymismahdollisuuksien on siis ajateltu riippuvan ensi sijassa suurimpien keskustensa globaalista kilpailukyvystä, mitä myös materiaaliset kehityskulut ovat tukeneet. Tämä on kohottanut isojen kaupunkien itsetuntoa ja vaikutusvaltaa sekä ohjannut kansallista alue- ja kaupunkipolitiikkaa nykyiseen suuntaansa.

Näiden perusargumenttien pätevyyttä Moisio perustelee varsin vakuuttavasti läpi kirjan ja sen kahdeksan toisiaan täydentävän luvun. Teoksen alkupuoli rakentaa käsitteellistä perustaa jäljempänä tuleville empiiris-teoreettisille osuuksille. Johdantoluvussa esitellään kirjan lähtökohtia, joista keskeisimpänä tuodaan esille tietoperustainen taloudellistuminen -käsite ja sen synty diskurssien, käytäntöjen ja materiaalisten prosessien tuloksena. Käsitteen tarkastelua syvennetään toisessa pääluvussa, jossa sen sisältö määritellään argumentoinnin, mielikuvien, tieteellisen ajattelun, kapitalistisen tuotannon, monikeskisen hallinnan sekä tilan tuottamisen yhteistuotokseksi. Kolmas luku puolestaan tarkastelee ylikansallistuvan valtion ja tietointensiivisen talouden yhteyttä. Luku esittelee teoksen loppuosaa jäsentävän jaon kolmeen tietoperustaisen globalisaation ulottuvuuteen, jotka ovat geopoliittiset diskurssit, geopoliittiset objektit ja geopoliittiset subjektit.

Luvut neljästä eteenpäin analysoivat tapaustutkimuksen tyylisesti tietoperustaisen taloudellistumisen geopoliittisia ulottuvuuksia. Neljäs pääluku analysoi asiantuntijoiden merkitystä diskurssien tuottajana ja sanoman levittäjinä. Tämän luvun ydintä on analyysi Michael Porterin ja hänen kansakunnan kilpailuetu -käsitteensä roolista alueellista kilpailua korostavan diskurssin sanansaattajana ja ajattelutavan juurruttajana eri puolille. Luvussa viisi siirrytään tarkastelemaan sitä, kuinka yksilöiden kiinnittyminen näihin diskursseihin synnyttää geopoliittisen subjektin. Tällä tarkoitetaan joukkoa ihmisiä, jotka ovat sisäistäneet tietointensiivisessä kapitalismissa menestymiseen tarvittavat tiedot, taidot, ajattelumallit ja arvomaailmat. Kuudes luku esittelee yliopistolaitoksen kansainvälistymisen ja geopoliittisen 
subjektin muodostumisen yhteyttä. Empiirisenä tapauksena toimii Aalto yliopiston insinöörikoulutus, jonka avulla Moisio osoittaa kuinka kansallisista intresseistä lähtenyt yliopistouudistus ja uudistuva yliopistokoulutus tuottavat uudenlaisen, tietoperustaista taloudellistumista tukevan geopoliittisen subjektin. Seitsemännessä pääluvussa tarkastellaan kaupunki-valtio -suhdetta ja sitä, kuinka tietointensiiviseen talouteen liittyvä luovuus on sulautunut osaksi kaupunkiympäristöä, suunnittelua ja politiikkaa. Tapauksina tässä luvussa toimivat Richard Floridan luovan luokan teoria ja Guggenheim museohankkeen suunniteluun ja epäonnistumiseen liittyneet vaiheet Helsingissä. Teoksen päättävä loppuluku tarjoaa synteesin kahdesta nykytilannetta luonnehtivasta geopolitiikan muodosta eli territoriaalisesta geopolitiikasta ja tietoperustaisen talouden geopolitiikasta. Samalla eritellään kriittisesti myös muutamia tietotalouteen liittyviä alueellisen ja sosiaalisen eriarvoistumisen piirteitä.

Sami Moision kirjaa voi lukea käsitteellisesti orientoituneena ja huolellisesti valikoituna tapaustutkimusten kokoelmana, jonka tapauksia ovat niin keskeiset tietotalousgurut kuin empiiriset paikallistutkimuksetkin. Kukin tapauksista pyrkii valottamaan tietotalouden geopolitiikkaa erilaisista mutta toisiinsa liittyvistä näkökulmista. Tapaustutkimuksen menetelmälle on luonteenomaista, että tapausten perusteella voidaan tehdä päätelmiä ilmiöitä tuottavista prosesseista, mutta tuloksista ei voi tehdä suoraviivaisia yleistyksiä näiden prosessien tuottamista ilmiöistä muissa paikoissa tai ajoissa. Yleistäminen tapahtuu analyyttisesti ja teoreettisesti, jolloin tapausempiriaa verrataan tai suhteutetaan muihin tutkimuksiin ja käsitteellisiin pohdintoihin. Tässä mielessä kirjaa kommentoineet kriitikot eivät osu täysin maaliinsa epäillessään Moision kirjassa esiteltyjen, suomalaisiin olosuhteisiin perustuvien tulosten ja päätelmien sopivuutta muun maailman olosuhteisiin (Sellar ym. 2020). Tulkitsen kuitenkin niin, että kirjan tavoitteena on ollut käsitteellistää ja auttaa ymmärtämään tietoperustaisen taloudellistumisen syvämekanismeja lähinnä Suomen kehityksen ja sieltä valittujen tapausten kautta. Niistä johdettujen päätelmien tarkoituskaan ei ole ollut kertoa empiirisistä tavoista, joilla samantyyppiset prosessit ilmenevät jossain muussa maantieteellisessä kontekstissa.

Niin kuin jo edellä tuli todettua, kirja onnistuu vakuuttamaan lukijansa perusargumenttien osalta huolellisesti toteutetun käsitteellisen ja empiirisen analyysin avulla. Argumentointi on paikoin niin perusteellista, että se kääntyy jo toiston puolelle. Tällä tietysti varmistetaan viestin perille meno, mutta samalla se tuo muuten suhteellisen sujuvaan tarinaan tiettyä kankeutta. Joka tapauksessa tietoperustainen taloudellistuminen diskursiivis-materiaalisena käsitteenä auttaa ymmärtämään viime vuosikymmenien tietotalouden ja tilanmuodostuksen yhteyksiä sekä tunnistamaan valtioiden ja paikkakuntien roolien vaihteluiden syitä muuttuvassa geotaloudellisessa ja -poliittisessa ympäristössä. Tällä tavoin kirja onnistuu erinomaisesti kirjoittajansa sille asettamassa tavoitteessa. Kuitenkin sitä lukiessa tulee tunne, että jotakin tarkastelusta jää uupumaan. Mieleen tulee ainakin kaksi näkökulmaa, jotka olisivat nähdäkseni syventäneet ja monipuolistaneet tarkastelua.

Kirja virittää pohdiskelemaan ympäristönäkökulman ja geopolitiikan yhteyttä, joka on rajattu ilmeisen tietoisestikin tämän kirjan ulkopuolelle. Ilmastonmuutos, lajikato, merien tila ja monet muut laajat ympäristökysymykset ovat tulleet merkittäviksi geopoliittisiksi kysymyksiksi. Erityisesti ilmastonmuutos materiaalis-diskurssiivisena ja poliittisena prosessina on viimeisen kymmenen vuoden aikana muodostunut keskeiseksi osaksi niin kansainvälistä kuin kansallistakin tilanmuodostusta. Ilmastonmuutos ja "hiilipuhunta" ovat läpäisseet nyky-yhteiskunnan globaalista paikalliseen esimerkiksi kansainvälisinä sopimuskamppailuina, kansallisten intressien ajamisina, EU regulaationa, aluepolitiikan sääntelynä sekä maankäytönsuunnittelun säädöksinä ja käytäntöinä. Vaikka alueiden menestymistä mitataan yhä edelleen pääsääntöisesti aineettomaan tietoon perustuvilla määreillä ja mittareilla, ovat niiden rinnalle tulleet materiaaliset hiilipäästöarvot ja -mittarit. Samalla ovat syntyneet eräänlaiset globaalit moraaliset ilmastomarkkinat, joissa maat, alueet ja kaupungit pyrkivät tavoittelemaan edelläkävijöiden asemaa ja arvostusta. Vaikka 
yhteydet tietoperustaiseen talouteen ovat moninaiset, ei ilmastonmuutokseen liittyviä tilamielikuvia täysin tavoiteta territoriaalisuuden ja verkoston käsitteillä. Se, miten tuota ilmastokeskustelun mukanaan tuomaa planetaarista tai vastaavaa tilamielikuvaa voisi käsitteellistää, vaatisi enemmän aikaa ja tilaa kuin tässä yhteydessä on käytettävissä.

Kirjan loppuosassa sivutaan varsin suppeasti tietoperustaisen talouden eriarvoistavia kehityskulkuja. Tässä yhteydessä voin hyvin yhtyä joidenkin kriitikoiden moitteeseen, jonka mukaan tietotalouden pimeä puoli jää liian vähälle huomiolle. Myös Moisio jakaa tämän huolen vastatessaan kommentoijille samassa julkaisussa. Hän nostaa erääksi aikamme keskeisistä haasteista sen, miten tietotaloutta pystyttäisiin ohjaamaan reilumpaan ja tasaarvoisempaan suuntaan (Sellar ym. 2020). Itse kirjassa paneudutaan kuitenkin kapean pelkistetysti ja muut näkökulmat pois rajaten perusargumentteihin tietoperustaisen taloudellistumisen diskurssiivisesta ja tilallisesta tuottamisesta. Tällöin keskitytään vain niihin toimijoihin ja alueisiin, joiden kautta tietotaloutta tuotetaan ja jotka ovat sen menestynyttä ydintä. Tällaisen rajauksen ongelmana on se, että kerrottu tarina näyttäytyy melkeinpä väistämättä menestyjien kertomuksena, vaikka kirjoittaja ei pohjimmiltaan sitä tavoittelisikaan.

Pimentoon jää helposti se kansalaisten ja paikkakuntien enemmistö, joka asemansa vuoksi on sosiaalisesti tai maantieteellisesti syrjässä virtojen tiloista ja tietotalouden ytimistä. Mielelläni olisinkin nähnyt jonkin empiirisen tapauksen myös suomalaisten häviäjien puolelta paikoista, joita voisi Rodríguez-Posea (2018) mukaillen luonnehtia tietotaloudellisesti merkityksettömiksi. Olisi ollut kiinnostavaa lukea, millaisena tietoperustainen taloudellistuminen näyttäytyy vaikkapa jossakin suomalaisessa pikkukaupungissa, joka on epätoivoisesti pyrkinyt pääsemään tietotalouden imuun. Se ei varmaankaan olisi ollut välttämätöntä kirjan argumentaation kannalta mutta olisi tuonut tarkasteluun tiettyä syvyyttä ja kriittistä otetta.

Jokainen tutkija tekee rajauksensa itse ja keskittyy itseään tutkimuksellisesti kiinnostaviin asioihin. Toiset voivat esittää siitä mielipiteensä, jotka nojautuvat kunkin arvioijan omiin lähtökohtiin. Sami Moision työ keskittyy perusargumenttiensa mukaiseen analysointiin ja käsitteellistämiseen onnistuen siinä tehtävässä mainiosti. Toivottavasti teos antaa virikkeitä tietoperustaisen taloudellistumisen erilaisia maantieteellisiä versioita tai rinnakkaisia geopoliittisia prosesseja tarkasteleville tutkijoille niin kansainvälisesti kuin Suomessakin.

\section{Lähteet}

Ritvala, T. \& Piekkari, R. (2021) Geopolitics of the knowledge-based economy. Journal of International Business Studies 52 334-337. https://doi.org/10.1057/s41267-020-00369-z

Rodríguez-Pose, A. (2018). The revenge of the places that don't matter (and what to do about it). Cambridge journal of regions, economy and society 11(1) 189-209. https://doi.org/10.1093/cjres/rsx024

Sellar, C., Jones, M., Wang, J., Gaffney, C., Kuus, M., Painter, J., Adams, P.C. \& Moisio, S. (2020). Reading Sami Moisio's Geopolitics of the Knowledge-Based Economy. Political Geography 80. https://doi.org/10.1016/j. polgeo.2020.102216 